\title{
Local strains Aspergillus oryzae KKB4 and Rhizopus oryzae KP1R1 as a reducing and detoxifying agents for deoxynivalenol
}

\author{
Andi Ardiansyah Arifin ${ }^{*}$, Francis Maria Constance Sigit Setyabudi² and Sardjono ${ }^{2}$ \\ ${ }^{1}$ Postgraduate Program of Food Science and Technology, Faculty of Agricultural Technology, Universitas Gadjah Mada, \\ Yogyakarta, Indonesia. \\ ${ }^{2}$ Department of Food and Agricultural Product Technology, Faculty of Agricultural Technology, Universitas Gadjah Mada, \\ Yogyakarta, Indonesia. \\ Email: adipangan.aa@gmail.com
}

Received 25 June 2018; Received in revised form 19 November 2018; Accepted 23 November 2018

\begin{abstract}
Aims: Deoxynivalenol is a type B trichothecene produced by Fusarium graminearum that can cause serious health problems in human and livestock. The present study aimed to reduce and detoxify deoxynivalenol using a local strain Aspergillus oryzae KKB4 and Rhizopus oryzae KP1R1.

Methodology and results: Corn as solid substrate artificially inoculated with F. graminearum bio 163252 to produce deoxynivalenol. Deoxynivalenol contaminated corn then inoculated with $A$. oryzae KKB4 and $R$. oryzae KP1R1. During fermentation, a decrease in deoxynivalenol levels is analyzed including loss of dry matter and glucosamine content. Deoxynivalenol was extracted from the substrate by solid phase extraction and quantified using high-performance liquid chromatography. The reduction of deoxynivalenol by $A$. oryzae KKB4 and $R$. oryzae KP1R1 were $65.91 \%$ and $56.82 \%$, respectively after ten days of fermentation. Toxicity analysis revealed that residues of deoxynivalenol were not toxic to growth of Saccharomyces cerevisiae cells.

Conclusion, significance and impact of study: Local strains $A$. oryzae KKB4 and $R$. oryzae KP1R1 were able to reduce and detoxify deoxynivalenol in solid substrates. This study provides supporting data to control mycotoxin that is critical for food and feed safety.
\end{abstract}

Keywords: Deoxynivalenol, Aspergillus oryzae KKB4, Rhizopus oryzae KP1R1, solid state fermentation

\section{INTRODUCTION}

Aspergillus, Penicillium, and Fusarium are three genera of fungus that generally contaminates plants during pre-, post-harvest, and storage. Among this group, Fusarium $\mathrm{sp}$. is a major contaminant in cereal crops such as barley, wheat and maize (Turner et al., 2009; Awad et al., 2010; Reddy et al., 2010). According to JECFA (2002), F. graminearum is mainly causing plants diseases and producing deoxynivalenol (DON). DON also known as the group of trichothecenes mycotoxin and most common toxin in cereals group. Although the toxicity level of DON is lower than other trichothecenes, its presence can be an indicator of other toxic trichothecenes (Lindblad et al., 2013; Kos et al., 2016).

The occurrence of DON contamination influenced by several factors such as substrate condition, the presence of fungal and another competitor microorganism, and the environmental condition (Bhat et al., 2010). Fusarium graminearum grow optimally at a temperature between 24.5 to $25.5{ }^{\circ} \mathrm{C}$ with aw0.977-0.995 (Neagu and
Borda, 2013). Indonesia has a warm and humid climate that suitable for fungal infection. The first case of DON contamination in Indonesian maize occurred at concentration 21 and 32 ng/g (Ali et al., 1998). Moreover, studies by Setyabudi et al. (2012) showed a higher concentration for contamination in maize at 47.5-205.7 $\mu \mathrm{g} / \mathrm{kg}$.

Since mycotoxins become important objective worldwide due to potential toxicity on human and animals, several decontamination strategies are needed to reduce the prevalence of mycotoxin contamination. The biological method is one of the promising approaches to reduce mycotoxin in food and feed using microorganisms. Several studies have demonstrated the ability of filamentous fungi to degrade mycotoxin. Aspergillus oryzae KKB4 can degrade aflatoxin B1 in a liquid medium (Sardjono et al., 2004a; 2004b) or in a solid substrate (Sardjono, 2008; Djunaidi et al., 2017). Similarly, $R$. oryzae can reduce aflatoxin in agar medium (Hackbart et al., 2014). 
Previous study has used bacteria and yeast to metabolize and detoxify DON (Fucsh et al., 2000). Meanwhile, Garda-Buffon and Badiale-Furlong (2010) describe the ability of $A$. oryzae and $R$. oryzae to degrade DON in the liquid media. However, not much literature shows the degradation of DON by fungi in a solid substrate. Solid substrate fermentation (SSF) has been widely published about considerable advantages compared to liquid fermentation, such as easy aeration, low energy requirements, higher metabolite production and easy product purification (Romano et al., 2007).

Residual levels of deoxynivalenol may cause longterm chronic toxicity due to accumulation in target organs. Therefore, analysis for assessing the toxicity of DON reduction product is essential, using a yeast Saccharomyces cerevisiae (Madhyastha et al., 1994; Binder, 1999; Tanaka et al., 2013). This study, henceforth, was to reduce and detoxify DON using a local strain of $A$. oryzae KKB4 and $R$. oryzae KP1R1 through solid state fermentation that produced fermented corn grains with no toxic effect.

\section{MATERIALS AND METHODS}

\section{Microorganisms and preparation of starter culture}

Fusarium graminearum bio 163252 was isolated from tomato by SEAMEO BIOTROP Bogor. Meanwhile, $A$. oryzae KKB4 (isolated from koji Kebumen area) and $R$. oryzae KP1R1 (isolated from koji Purwokerto area) by Prof. Sardjono and collected at Laboratory of Biotechnology, Faculty of Agricultural Technology, Universitas Gadjah Mada, Yogyakarta. Medium for starter culture was rice grain sterilized at $121^{\circ} \mathrm{C}$ for $20 \mathrm{~min}$. Then inoculated with spore suspension from 7 days agar slant using $0.05 \%$ tween 80 . The incubation of starter was done at room temperature for 7 days, and later dried then ground into rough powder, so the starter powder was ready to be used for inoculation (Sardjono et al., 2004b; Sardjono 2008; Shi et al., 2014).

\section{Production of DON in corn grains}

About $5 \mathrm{~kg}$ of yellow corn grains was sterilized by a dry heating method in an oven at $170{ }^{\circ} \mathrm{C}$ for $2 \mathrm{~h}$. Sterile corn was moistened with sterile water $(2: 1)$ and then inoculated with $0.1 \%$ starter $F$. graminearum bio 163252 . The inoculated corn was distributed over perforated tray and placed in a closed rack fermentation. The corn was then incubated for seven days at room temperature. After seven days, the fungal growth was stopped by dry sterilization at a temperature of $170{ }^{\circ} \mathrm{C}$ for $2 \mathrm{~h}$ (Gupta et al., 2011).

\section{Reduction of DON by $A$. oryzae KKB4 and $\boldsymbol{R}$. oryzae KP1R1}

Sterile distilled water is added to contaminated corn grains in ratio $1: 2$ and each of $0.1 \%$ starter $A$. oryzae KKB4 and $R$. oryzae KP1R1 inoculated separately to contaminated wet corn grains. Incubation was conducted in the incubator rack equipped with a reserve of water in the bottom part to achieve a relative humidity above $90 \%$ during fermentation. Incubation is carried out at room temperature for ten days.

\section{Loss of dry matter}

Loss of dry matter was calculated from the weight of corn grains in day $0,2,4,6,8$ and 10 fermentation. Approximately $1 \mathrm{~g}$ sample was dried at $105^{\circ} \mathrm{C}$ until a constant weight was achieved (Smits et al., 1996).

\section{Glucosamine content}

Estimation of fungal mass was determined by hydrolysis of chitin contained in the cell wall into the $\mathrm{N}$-acetyl glucosamine. Approximately $0.2 \mathrm{~g}$ dry sample was added $5 \mathrm{~mL}$ of $\mathrm{HCl} 6 \mathrm{M}$. The mixture was then put in an autoclave at $121^{\circ} \mathrm{C}$ for $8 \mathrm{~min}$. The mixture is cooled and filtered. Then the volume is adjusted to $5 \mathrm{~mL}$ using aquabidest. The glucosamine content was measured based on the methods as described Souza et al. (2011). The absorbance was measured at $530 \mathrm{~nm}$ using a spectrophotometer. Glucosamine hydrochloride (Sigma) was used as a standard.

\section{Extraction, purification, and determination of DON}

A total of $25 \mathrm{~g}$ samples was homogenized with $100 \mathrm{~mL}$ of a mixture of acetonitrile: Water $(80: 20)$ in a blender for 3 min. The mixture was filtered using a Whatman paper No $4.4 \mathrm{~mL}$ of the obtained solutions purified by passage on a solid phase extraction (SPE). Two millilitre of the obtained eluate was dried using a nitrogen evaporator, and then reconstituted with $500 \mu \mathrm{L}$ acetonitrile: Water (10:90) and subsequently analyzed for levels of Deoxynivalenol (Klotzel and Lauber, 2017).

The analysis was carried out using High-Pressure Liquid Chromatography (HPLC) with reverse phase C18 column ( $5 \mu \mathrm{m}$ particle size, $150 \times 4.6$ i.d, Shimpack), detector ultraviolet, wavelength $218 \mathrm{~nm}$, mobile phase acetonitrile: Water $(10: 90)$ and the flow rate $0.6 \mathrm{~mL} / \mathrm{min}$. To calculate the DON sample concentration, the standard DON range (Supelco) is $25.00-3200.00 \mathrm{ng} / \mathrm{mL}$ which is used to create the DON standard curve (Kotal and Radova, 2002).

\section{Toxicity assay}

This analysis to confirm toxicity of the DON reduction products by using a yeast $S$. cerevisiae. Toxicity was determined by measuring optical density at $600 \mathrm{~nm}$ and viability of yeast cells after incubation at $30{ }^{\circ} \mathrm{C}$ for $48 \mathrm{~h}$ (modified from Binder, 1999; Sardjono et al., 2004b). The filtered solution that had been already prepared from DON analysis were used for this assay. Precisely $10 \mathrm{~mL}$ solution was evaporated using nitrogen evaporator in 15 $\mathrm{mL}$ test tube; then residues were dissolved in $4 \mathrm{~mL}$ Peptone Glucose Yeast broth and later inoculated with 
$0.4 \mathrm{~mL}$ suspension of $S$. cerevisiae (cell viability $5.5 \times 10^{6}$ CFU $/ \mathrm{mL})$.

\section{Statistical analysis}

All experiments were conducted in triplicate. Data were analyzed using the Excel program (Microsoft), and the averaged results were expressed as the mean \pm standard deviation.

\section{RESULTS AND DISCUSSION}

Aspergillus oryzae KKB4 and $R$. oryzae KP1R1 growth and metabolic activity during solid-state fermentation

During fermentation, the growth of fungus can be observed using glucosamine content analysis (Smits et al., 1996; Terebiznik and Pilosof, 1999). Figure 1 shows the accumulated pattern of increase in glucosamine as an indicator of fungal biomass during fermentation by $A$. oryzae KKB4 and $R$. oryzae KP1R1. In the figure shows the ability of $A$. oryzae KKB4 and $R$. oryzae KP1R1 to growing well on corn substrates. During the fermentation, there was an increase of glucosamine accumulation and on the $10^{\text {th }}$ day reached $6.528 \pm 5.752 \mathrm{mg} / \mathrm{g}$ and $1.079 \pm$ $0.556 \mathrm{mg} / \mathrm{g}$ by $A$. oryzae KKB4 and $R$. oryzae KP1R1 respectively.

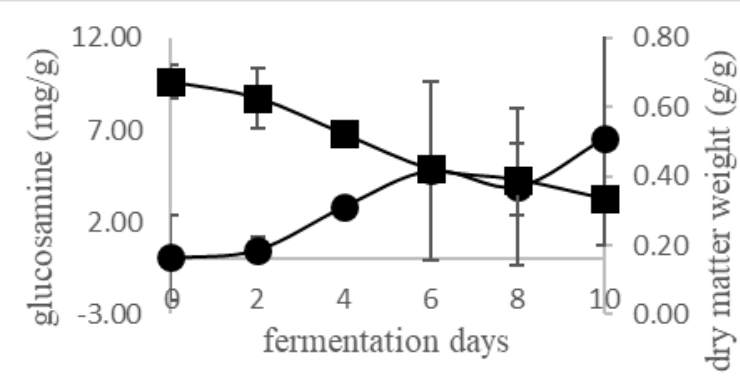

A
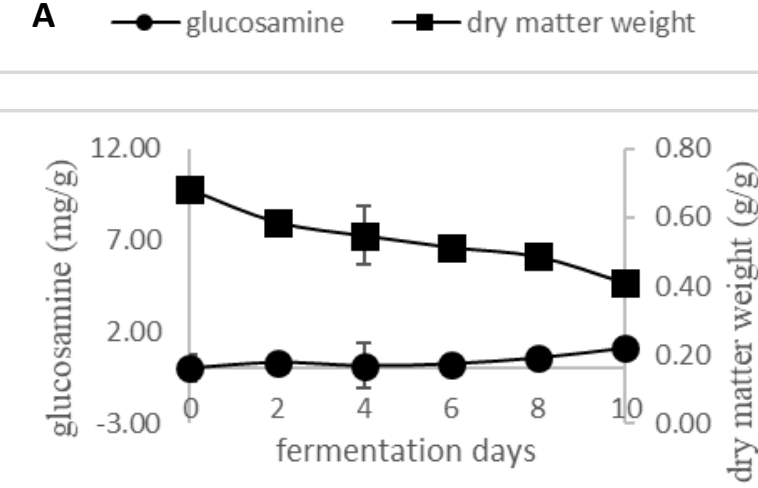

B

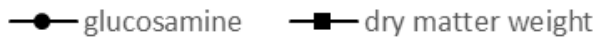

Figure 1: The pattern of growth profile; (A) Aspergillus oryzae KKB4 and (B) Rhizopus oryzae KP1R1.
Terebiznik and Pilosof (1999) and Sardjono (2008) revealed that the growth of fungal in SSF system has a good correlation with the loss of dry matter weight. Substrate changes characterized by high water loss, loss of dry matter and increased $\mathrm{CO}_{2}$ production indicate metabolic activity of the fungal. During fermentation, the substrate will lose weight because it is used for growth and production of metabolites. The use of corn substrate by $A$. oryzae KKB4 and $R$. oryzae KP1R1 each caused dry matter loss of $0.336 \pm 0.032 \mathrm{~g} / \mathrm{g}$ and $0.409 \pm 0.004 \mathrm{~g} / \mathrm{g}$ on the $10^{\text {th }}$ day of fermentation.

The pattern of glucosamine change and changes in the weight of the dry matter during fermentation by $A$. oryzae KKB4 and $R$. oryzae KP1R1 can be seen in Figure 1. The image shows an increase in glucosamine in line with dry matter loss which is an indicator of metabolic activity. The difference in the rise of glucosamine between $A$. oryzae KKB4 with $R$. oryzae KP1R1 is thought to be due to $A$. oryzae KKB4 using corn substrate dominant for biomass growth characterized by high glucosamine rise. While $R$. oryzae KP1R1 uses corn substrate more to produce metabolite compared to biomass growth so that glucosamine increase is not too high.

\section{DON reduction by $A$. oryzae KKB4 and $R$. oryzae KP1R1}

Fermentation by $A$. oryzae KKB4 and $R$. oryzae KPR1 has an exciting result to decreased levels of deoxynivalenol on corn, correlated between fermentation periods and fungal biomass as described in Figure 2. Aspergillus oryzae KKB4 can decrease the DON level from $397.49 \mathrm{ng} / \mathrm{g}$ on the first day to $135.52 \mathrm{ng} / \mathrm{g}$ at the end of fermentation. While $R$. oryzae KP1R1 can reduce the DON level from $399.41 \mathrm{ng} / \mathrm{g}$ to $172.46 \mathrm{ng} / \mathrm{g}$. In the fermentation process, it is suspected to be degraded by a mechanism such as adsorption of mycotoxin by fungi (Garda-Buffon and Badiale-Furlong, 2010) and or extracellular enzyme activity which can reduce mycotoxin (Sardjono et al., 2004a; Garda-Buffon et al., 2011).

Figure 2 also illustrates the relationship between biomass growth and decreased levels of DON by $A$. oryzae KKB4 and $R$. oryzae KP1R1. During fermentation, the biomass production of $A$. oryzae KKB4 is high enough and the increase in biomass followed by a decrease in DON levels. It is suspected that the growing mycelia of $A$. oryzae KKB4 can produce an enzyme that degrade DON. While $R$. oryzae KP1R1 has a biomass production that is not too high but shows a constant decrease in DON levels until the end of fermentation. This difference is estimated because $R$. oryzae KP1R1 uses a substrate to produce DON degrading enzymes more dominant than for biomass growth. Thus either $A$. oryzae KKB4 and $R$. oryzae KP1R1 could degrade DON.

During the fermentation of solid substrate, the fungus will degrade the substrate to take its nutrients (Gowthaman et al., 2001). Corn is one of the food commodities that have essential nutrients for $A$. oryzae KKB4 and $R$. oryzae KP1R1. After getting the nutrients, they can grow well, and growth can be observed through 
the glucosamine content. They also simultaneously release primary or secondary metabolites that have the potential to degrade and detoxify DON. The biologicalreduction of mycotoxins by solid substrate fermentation is influenced by several factors such as starter spores, fermentation process conditions, substrate composition and initial concentrations of mycotoxins (Gowthaman et al., 2001; Hackbart et al., 2014).

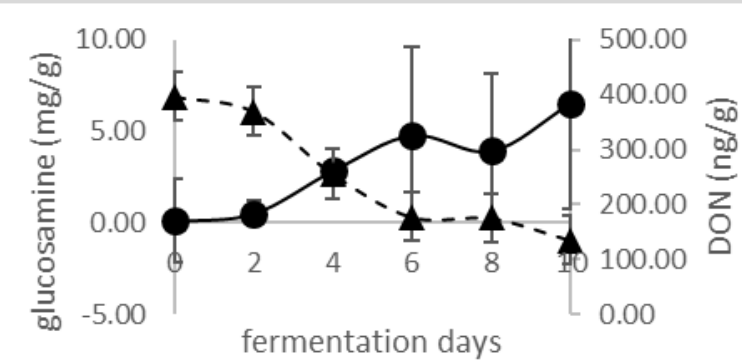

\section{A}
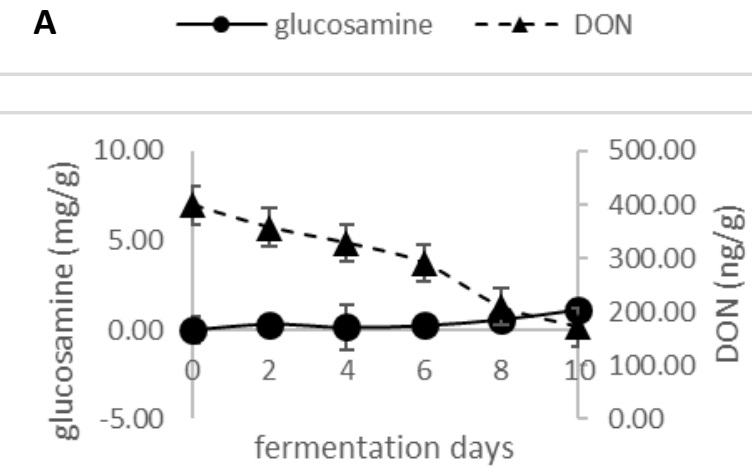

B

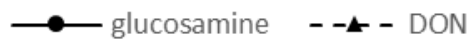

Figure 2: The correlation between fungal biomass and levels of DON; (A) Aspergillus oryzae KKB4 and (B) Rhizopus oryzae KP1R1.

\section{DON detoxification by $A$. oryzae KKB4 and $R$. oryzae KP1R1}

Several previous studies just focused on reducing DON levels without considering the safety of the degradation products. In this research, toxicity test of fermentation products by $A$. oryzae KKB4 and $R$. oryzae KP1R1 was conducted using yeast $S$. cerevisiae. Trichothecenes are potent inhibitors of protein biosynthesis in eukaryotic cells due to receptor like binding sites on $80 \mathrm{~S}$ ribosomes, leading to an inhibition of peptidyl transferase (Binder et al., 1997; Binder, 1999). Thus, another application for testing toxicity of trichothecenes is by inhibition of yeast cell growth.

The growth of $S$. cerevisiae cells was inhibited by the pure standard of DON, as identified in Figure 3. It was clearly that there decreased optical density and cell viability values in $500 \mathrm{ng} / \mathrm{mL}$ DON. Consequently, 500 $\mathrm{ng} / \mathrm{mL}$ DON was an initial toxicity limit in disrupting cell growth.

The successful DON detoxification by $A$. oryzae KKB4 and $R$. oryzae KP1R1 in 10 days fermentation has been exhibited in Figure 4. The medium containing $500 \mathrm{ng} / \mathrm{mL}$ DON standard had adverse effects on the cell growth. Meanwhile, a medium that containing fermentation samples by $A$. oryzae KKB4 and $R$. oryzae KP1R1 after being concentrated to reach the same concentration as the initial toxic concentrations of DON did not give a side effect in disruption to cell growth. As a result, the cells had still grown normally. Although, its sample had a half DON concentration with the maximum limit of DON at $1000 \mathrm{ng} / \mathrm{g}$; the DON reduction products by $A$. oryzae KKB4 and $R$. orzyae KP1R1 had no toxic effects on $S$. cerevisiae cells. It might be happened since DON reduction by $A$. oryzae KKB4, and $R$. oryzae KP1R1 was enzymatic and resulting in the changing of DON structure (data not shown), such as disrupting the double bond in the A-ring at $\mathrm{C9}$, disrupting the R5 keto functional group at C8 and modification at C3 (Foroud et al., 2016). Studies by Borzekowski et al. (2018) showed that genera Aspergillus and Rhizopus can reduce the toxicity by glycosylation at C3 in trichothecenes.
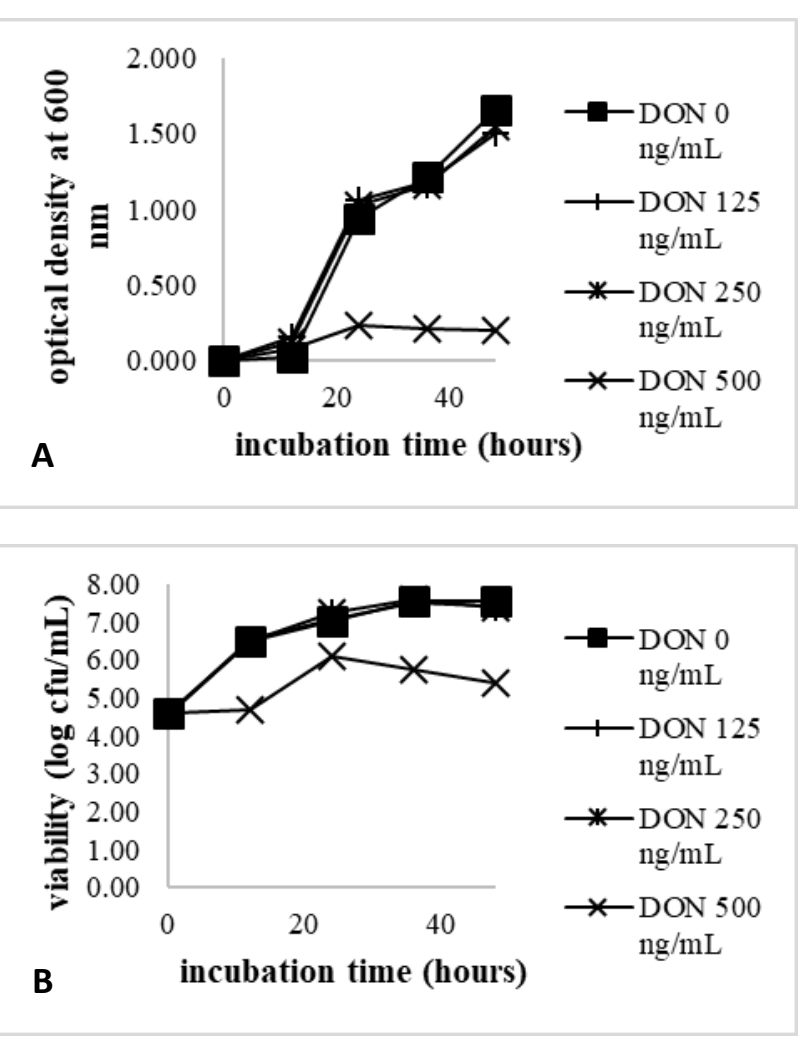

Figure 3: The growth of $S$. cerevisiae cell in $P G Y$ broth mixed with DON standard solution $(A)$ optical density at $600 \mathrm{~nm}$ and (B) cell viability. 

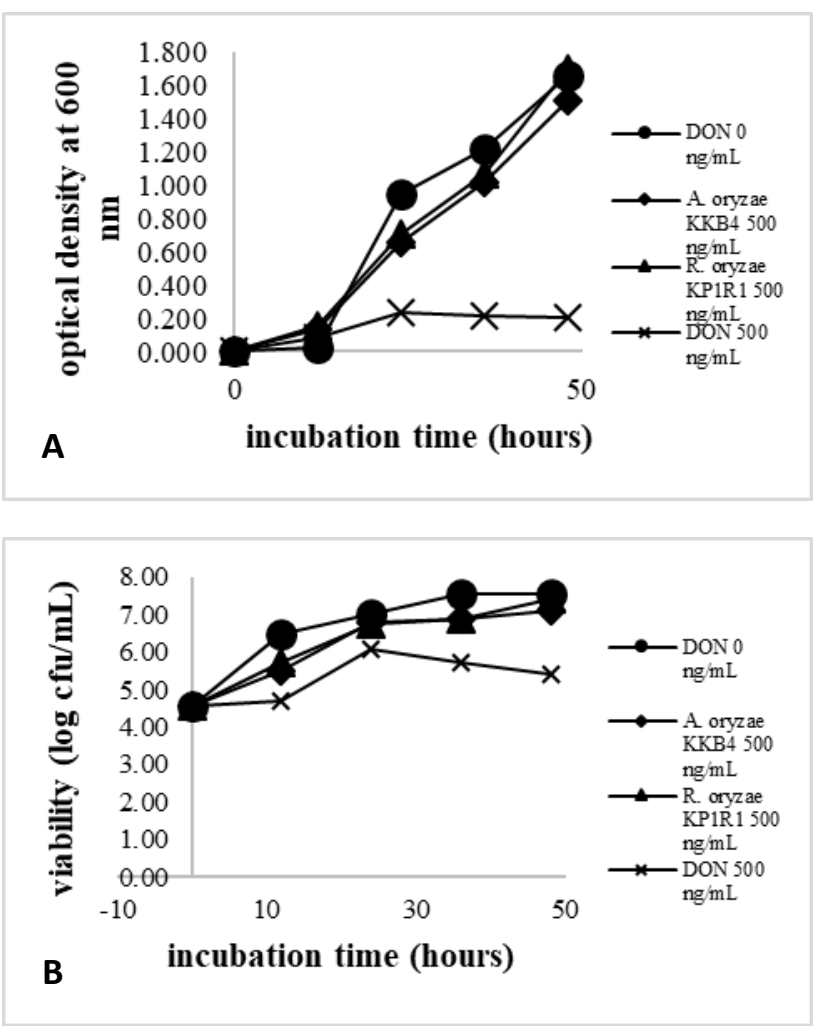

Figure 4: Toxicity of DON degradation products; (A) optical density at $600 \mathrm{~nm}$ and (B) cell viability.

\section{CONCLUSION}

Based on the results, $A$. oryzae KKB4 and $R$. oryzae KP1R1 were able to reduce DON concentration in contaminated corn through solid-state fermentation. The toxicity results in this bioassay revealed that $A$. oryzae KKB4 and $R$. orzyae KP1R1 could also detoxify and produced fermented corn which has no toxic effects to Saccharomyces cerevisiae.

\section{ACKNOWLEDGEMENTS}

This work was financially supported by Synergy Research Grant of Faculty of Agricultural Technology, Universitas Gadjah Mada. The author also thanks to Mr. Purwito, Mrs. Novi Dwinawati and Mr. Anang Juni Yastanto for the kindness and technical support during the research.

\section{REFERENCES}

Ali, N., Sardjono., Yamashita, A. and Yoshizawa, T. (1998). Natural co-occurence of aflatoxins and Fusarium mycotoxins (fumonisins, deoxynivalenol, nivalenol and zearalenone) in corn from Indonesia. Food Additives Contaminants 15, 377-384.

Awad, W. A., Ghareeb, K., Böhm, J. and Zentek, J. (2010). Decontamination and detoxification strategies for the Fusarium mycotoxin deoxynivalenol in animal feed and the effectiveness of microbial biodegradation. Food Additives and Contaminants 27, 510-520.

Bhat, R., Rai, R. V. and Karim, A. A. (2010). Mycotoxin in food and feed: Present status and future concerns. Comprehensive Reviews in Food Science and Food Safety 9, 57-81.

Binder, J., Horvath, E. M., Heidegger, J., Ellend, N., Danner, H., Krska, R. and Braun, B. (1997). A bioassay for comparison of the toxicity of trichothecenes and their microbial metabolites. Cereal Research Communication 25(3), 489-491.

Binder, J. (1999). A yeast bioassay for Trichothecenes. Natural Toxins (7), 401-406.

Borzekowski, A., Drewitz, T., Keller, J., Pfeifer, D., Kungte, H. J., Koch, M., Rohn, S. and Maul, R, (2018). Biosynthesis and characterization of zearalenone-14-sulfate, zearalenone-14-glucoside, and zearalenone-16-glucoside using common fungal strains. Toxins 10, 1-15.

Djunaidi, C. S., Setyabudi, F. M. C. S. and Sardjono. (2017). The role of Aspergillus oryzae KKB4 in reducing and detoxifying aflatoxin B1 applied in moistheated corn. Malaysian Journal of Microbiology 13(2), 117-123.

Fuchs, E., Binder, E. M., Heidler, D. and Krska, R. (2000). Characterisation of metabolites after the microbial degradation of A-and B-trichothecenes by BBSH 797. Mycotoxin Research 16(1), 66-69.

Foroud, N. A., Shank, R. A., Kiss, D., Eudes, F. and Hazendonk, P. (2016). Solvent and water mediated structural variations in deoxynivalenol and their potential implications on the disruption of ribosomal function. Frontiers in Microbiology 7(1239), 1-15.

Garda-Buffon, J., and Badiale-Furlong, E. (2010). Kinetics of deoxynivalenol by Aspergllus oryzae and Rhizopus oryzae in submerged fermentation. Journal of The Brazilian Chemical Society 21, 710-714.

Garda-Buffon, J., Kupski, L. and Badiale-Furlong, E. (2011). Deoxynivalenol (DON) degradation and peroxidase enzyme activity in submerged fermentation. Ciência e Tecnologia de Alimentos, Campinas 31(1), 198-203.

Gowthaman, M. K., Khrisna, C. and Moo-Young, M. (2001). Fungal solid-state fermentation. In: An Overview. Khachatourians, G. G. and Arora, D. K. (eds.). Applied Mycology and Biotechnology, Elsevier Science B. V. pp. 1,305-1,351.

Gupta, V. K., Chattopadhyay, P., Kalita, M. C., Chaurasia, A. K., and Kumar, H. (2011). Isolation and determination of deoxynivalenol by reversed phase high pressure liquid chromatography. Pharmaceutical Methods 2, 25-29.

Hackbart, H. C. S., Machado, A. R., Christ-Ribiero, A., Prietto, L. and Badiale-Furlong, E. (2014). Reduction of aflatoxin by Rhizopus oryzae and Trichoderma reesei. Mycotoxin Research 30, 141-149. JECFA. (2002). Evaluation of certain mycotoxins in food. WHO Technical Report Series 906. Joint FAOMHO 
Expert Committee on Food Additives. 56th Report. Geneva. Switzerland.

Klotzel, M. and Lauber, U. (2017). New SPE sorbent for clean-up of fusarium toxin-contaminated cereals and cereal-based foods, bond elut mycotoxin. Application Note. http://www.agilent.com/cs/library /applications/SI-00295.pdf [Retrieved on 21 August 2017].

Kos J., Hajnal E. J., Šarić B., Jovanov P., Nedeljković N., Milovanović I. and Krulj, J. (2016). The influence of climate conditions on the occurrence of deoxynivalenol in maize harvested in Serbia during 2013-2015, Food Control 30, 734-740.

Kotal, F. and Radova, Z. (2002). A simple method for determination of deoxynivalenol in cereals and flours. Czech Journal of Food Science 20, 63-68.

Lindblad M., Gidlund A., Sulyok M., Börjesson T., Krska R., Olsen M. and Fredlund E. (2013). Deoxynivalenol and other selected Fusarium toxins in Swedish wheat: Occurrence and correlation to specific Fusarium species. International Journal of Food Microbiology 167, 284-291.

Madhyastha, M. S., Marquadt, R. R., Frohlich, A. A. and Borsa, J. (1994). Optimization of yeast bioassay for trichothecene mycotoxins. Journal of Food Protection 57(6), 490-495.

Neagu, C. and Borda, D. (2013). Modelling the growth of Fusarium graminearum on barley and wheat media extract. Romanian Biotechnological Letters 18, 84898498.

Reddy, K. R. N., Salleh, B., Saad, B., Abbas, H. K., Abel, C. A., and Shier, W. T. (2010). An overview of mycotoxin contamination in foods and its implications for human health. Toxin Reviews 29, 3-26.

Romano, D., Gandolfi, R., Gualandris, R., Romano, A., Starace, F., Villa, R., and Molinari, F. (2007). Solid state fermentation for the production of lipolytic fungal enzymes. Annals of Microbiology 57, 561-564.

Sardjono., Rahayu, E. S., Raharjo, S. and Rahayu, K. (2004a). Detoxification of aflatoxin B1 by extracellular enzymes of Aspergillus oryzae KKB4. Indonesian Food and Nutrition Progress 11, 30-34.

Sardjono., Raharjo, S., Rahayu, E. S. and Kuswanto K.R. (2004b). The role of extracellular enzymes produced by Aspergillus oryzae KKB4 in biodegradation of aflatoxin $\mathrm{B}_{1}$. Indonesian Food and Nutrition Progress 11, 65-71.

Sardjono. (2008). The growth kinetics of Aspergillus oryzae KKB4 on solid state culture system and the activity of crude extracellular enzyme on reducing aflatoxin B1. Agritech 28, 145-149.

Setyabudi, F. M. C. S., Nuryono, N., Wedhastri, S., Mayer, H. K. and Razzazi-Fazeli, E. (2012). Limited survey of deoxynivalenol occurence in maize kernels and maize-products collected from Indonesian retail market. Food Control 24, 123-127.

Shi, C., Yan, P., Li, J., Wu, H., Li, Q. and Guan, S. (2014). Biocontrol of Fusarium graminearum growth and deoxynivalenol production in wheat kernels with bacterial antagonists. International Journal of
Environmental Research and Public Health 11, 10941105.

Smits, J. P., Rinzema, A., Tramper, J., Schlosser, E. E. and Knol, W. (1996). Accurate determination of process variables in a solid-state fermentation system. Process Biochemistry 31, 669-678.

Souza, M. M. de, Prietto, L., Ribeiro, A. C., Souza, T. D. de, and Badiale-Furlong, E. (2011). Assessment of the antifungal activity of Spirulina platensis phenolic extract against Aspergillus flavus. Lavras 35, 10501058.

Tanaka, A., Yamane, Y., Komiya, Y., Yamauchi, K., Sugiyama, T., Echigo, A., Usami, R., Yoshida, Y., Abe, F., Minegishi, H. and Takahashi-Ando, N. (2013). Development of a highly sensitive yeast bioassay for trichothecene detection. Mycotoxins 63(2), 161-170.

Terebiznik, M. R. and Pilosof, A. M. R. (1999). Biomass estimation in solid state fermentation by modelling dry matter weight loss. Biotechnology Technique 13, 215219.

Turner, N. W., Subrahmanyam, S. and Piletsky, S. A. (2009). Analytical methods for determination of mycotoxin: A review. Analytica Chimica Acta 632, 168-180. 